\title{
Communication
}

\section{The Potential Effect of Elevated Root Zone Temperature on the Concentration of Chlorogenic, Caffeic, and Ferulic acids and the Biological Activity of Some Pigmented Solanum tuberosum L. Cultivar Extracts}

\author{
Hildegard Witbooi ${ }^{1}$ (D), Callistus Bvenura ${ }^{1}$, Anna-Mari Reid ${ }^{2}$ (D), Namrita Lall ${ }^{2,3}$ (iD, \\ Oluwafemi Omoniyi Oguntibeju ${ }^{4}$ (D) and Learnmore Kambizi ${ }^{1, *}$
}

check for updates

Citation: Witbooi, H.; Bvenura, C.; Reid, A.-M.; Lall, N.;

Oguntibeju, O.O.; Kambizi, L. The Potential Effect of Elevated Root Zone Temperature on the Concentration of Chlorogenic, Caffeic, and Ferulic acids and the Biological Activity of Some Pigmented Solanum tuberosum L. Cultivar Extracts. Appl. Sci. 2021, 11, 6971. https://doi.org/10.3390/ app11156971

Academic Editors: Luca Mazzoni, Maria Teresa Ariza Fernández and Franco Capocasa

Received: 16 June 2021

Accepted: 15 July 2021

Published: 29 July 2021

Publisher's Note: MDPI stays neutral with regard to jurisdictional claims in published maps and institutional affiliations.

Copyright: (c) 2021 by the authors. Licensee MDPI, Basel, Switzerland. This article is an open access article distributed under the terms and conditions of the Creative Commons Attribution (CC BY) license (https:/ / creativecommons.org/licenses/by/ $4.0 /)$.
1 Department of Horticulture, Faculty of Applied Sciences, Cape Peninsula University of Technology, Bellville 7535, South Africa; hildegardwitbooi@gmail.com (H.W.); bvenurac@cput.ac.za (C.B.)

2 Department of Plant \& Soil Sciences, Medicinal Plant Sciences, University of Pretoria, Pretoria 0002, South Africa; u29086354@tuks.co.za (A.-M.R.); namrita.lall@up.ac.za (N.L.)

3 School of Natural Resources, University of Missouri, Columbia, MO 65211, USA

4 Phytomedicine \& Phytochemistry Group, Oxidative Stress Research Centre, Department of Biomedical Sciences, Faculty of Health and Wellness Sciences, Cape Peninsula University of Technology, Bellville 7530, South Africa; Oguntibejuo@cput.ac.za

* Correspondence: kambizil@cput.ac.za

Abstract: Without a doubt, potatoes play a vital food and nutrition security role in the world as more than a billion people consume this vegetable. Furthermore, the polyphenolic constituents of pigmented potato cultivars and their associated health benefits have been reported. However, the antioxidant, anticancer, and antimycobacterial activity of pigmented cultivars are scanty. Therefore, the present study explores the phenolic acids and biological activities of cv. Salad Blue (SB) and non-pigmented control (BP1) extracts. The antiproliferative activity of S. tuberosum L. against human hepatocellular carcinoma (HepG2) was investigated, as well as the ability to inhibit Mycobacterium smegmatis. Chlorogenic acid was the most prominent phenolic acid in both treatments as well as cultivars. In the current trial, $24^{\circ} \mathrm{C}$ significantly increased chlorogenic acid in cv. SB and $\mathrm{BP} 1$. Ethanolic extracts of all the samples showed no activity at the highest test concentration of $1000 \mu \mathrm{g} / \mathrm{mL}$ (ciprofloxacin MIC of $0.325 \mu \mathrm{g} / \mathrm{mL}$ ) against $M$. smegmatis. The antiproliferative activity of the tuber samples against HepG2 liver cells had $\mathrm{IC}_{50}$ values ranging between $267.7 \pm 36.17 \mu \mathrm{g} / \mathrm{mL}$ and $>400 \mu \mathrm{g} / \mathrm{mL}$. Since the health benefits of these cultivars are highly valued, the present study provides useful information for future oncology studies, for human nutrition, as well as for how these underutilized cultivars can be fortified to improve their health benefits.

Keywords: Solanum tuberosum; antimycobacterial; antioxidant capacity; hepatocellular carcinoma; pigmented potatoes

\section{Introduction}

Of the crops that feed the world, potatoes are the third most consumed after rice and wheat, with more than a billion people relying on them for food and nutrition security [1]. This is because they are an important staple crop that is well endowed with complex carbohydrates and thus very high in energy, in addition to other nutritional benefits. This crop is easy to cultivate under a diverse range of climatic conditions except those found in Antarctica [2]. Latest statistics indicate that by 2019, over 17 million hectares were under potato cultivation. Global production also increased from 334.73 to 370.43 million metric tons (MMT) between 2009 and 2019 [2]. Current data [3] further show that global leaders in potato production by MMT are the following: China (91.92) > India (50.19) > Russia (22.07) > Ukraine (20.27) > USA (19.18) > Germany (10.60) > Bangladesh (9.65) > France (8.56) > Netherlands (6.96) > Poland (6.48). 
In South Africa, potatoes also play a major food and nutrition security role, with about $677.46 \mathrm{~km}^{2}$ under potato cultivation in the 2016/2017 agricultural season [4]. Furthermore, during the 2016/2017 agricultural season, about 2.5 MMT of potatoes were produced at a rate of approximately $3,617,200 \mathrm{~kg} / \mathrm{km}^{2}$ [4]. According to the same statistics, the average per capita consumption of potatoes in South Africa is $30 \mathrm{~kg}$.

The usefulness of the potato peel, which is regarded as a waste product, has grown $[5,6]$. Due to its high antioxidant and antimicrobial effectiveness [7], it is used in food preservation. The potato peel has also been reported as a pharmaceutical ingredient in wound management [8,9], and glycoalkaloids in the leaves and other parts of the plant have been reported to offer natural protection against plant pests [10,11].

In the world today, the demand for polyphenolic and vitamin rich food sources is on the rise, and pigmented potatoes, among other crops, often possess these constituents [12].

Potatoes are rich in phenolic compounds; for example, about $49 \%$ to $90 \%$ of the total phenolics in this vegetable are in fact chlorogenic acid [13,14]. In addition, as shown in some epidemiological studies, a clear correlation has been established between consuming phenolic rich diets and better health [15-18]. Nevertheless, the antioxidant activity and some health promoting aspects of plant-derived phenolic compounds cannot be overemphasized. Anthocyanins in some pigmented potato cultivars have been reported to suppress stomach cancer in mice [19], prostate cancer cells [20], colon cancer cells [21], as well as liver cancer cells [22]. Furthermore, glycoalkaloids in these cultivars have been shown to inhibit the growth of colon, liver, stomach, and lymphoma cancer cells, among others [23,24]. However, the potential role of root zone temperature (RZT) on antioxidant, anticancer, as well as antimycobacterial activity of pigmented cultivar extracts has not been reported. We previously reported root zone temperature's role on physiological growth and polyphenolic contents in both pigmented and non-pigmented potato cultivars [25]. The results of this study showed the polyphenolic superiority of pigmented cultivars under a diverse range of root zone temperatures over the non-pigmented cultivar. Therefore, as an offshoot of this study, we tested the antiproliferative activity of the extracts of both the pigmented and non-pigmented cultivars against liver hepatocellular carcinoma (HepG2) cells and their antimycobacterial activity against $M$. smegmatis. In addition, chlorogenic and caffeic acid were significantly higher in SB under $24^{\circ} \mathrm{C}$ in our previous study, and this informed our decision for the selected temperature and cultivar of the current study.

\section{Materials and Methods}

\subsection{Plant Growth, Harvest, and Extraction}

Potato tubers of cv. BP1 and SB were cultivated in a greenhouse, as described by [25], for 73 days to test the effect of controlled RZT $\left(24^{\circ} \mathrm{C}\right.$ ) and non-controlled RZT (ranging between $19{ }^{\circ} \mathrm{C}$ and $25^{\circ} \mathrm{C}$ ). Postharvest, the samples were separated into flesh and skin, and frozen at $-80^{\circ} \mathrm{C}$ in paper bags, after which they were freeze dried for $24 \mathrm{~h}$ in a VirTis genesis wizard 2.0 (UK). The samples were then powdered and sieved through a 40-60 mesh and stored at $4{ }^{\circ} \mathrm{C}$ until further use. About $200 \mathrm{~g}$ of the powdered and lyophilized tubers were extracted with $20 \times$ the volume of $60 \%$ ethanol $(\mathrm{EtOH})$ (Absolute; B\&M Scientific) per mass $(10 \mathrm{~g}>200 \mathrm{~mL})$ overnight and then ultra-sonicated for approximately $15 \mathrm{~min}$ at $40^{\circ} \mathrm{C}$. Samples were filtered using $0.22 \mu \mathrm{m}$ syringe filters $(25 \mathrm{~mm})$ and concentrated using the Genevac miVac sample concentrator.

\subsection{Phytochemical Analysis}

A Dionex HPLC (Dionex Softron, Germering, Germany) was used to determine chlorogenic, caffeic, and ferulic acids in the samples. This HPLC has a Brucker ESI Q-TOF MS coupled autosampler and is equipped with a binary solvent manager. A reversed chromatography on a Thermo Fisher Scientific C18 column $5 \mu \mathrm{m}, 4.6 \times 150 \mathrm{~mm}$ (Bellefonte, PA, USA) was used to separate plant extract constituents via the use of a linear gradient of $0.1 \%$ formic acid in acetonitrile (solvent $\mathrm{A}$ ) and water (solvent $\mathrm{B}$ ) at $0.8 \mathrm{~mL} \mathrm{~min}{ }^{-1}$ flow rate, an electrospray voltage of $+3500 \mathrm{~V}$, an oven temperature of $30^{\circ} \mathrm{C}$, and a $10 \mu \mathrm{L}$ injection 
volume. The negative mode was used to acquire the MS spectra. The nebulizer gas was set at 35 psi and the dry gas to $9 \mathrm{~L} \mathrm{~min}^{-1}$ at $300^{\circ} \mathrm{C}$.

\subsection{Antimycobacterial Activity of the Ethanolic Extract of Solanum tuberosum L.}

Mycobacterium smegmatis (M. smegmatis) is a non-pathogenic and fast-growing species of mycobacterium. This model is most used in the physiology of mycobacteria, as it has relevance to the pathogenic species of Mycobacterium tuberculosis, the causative pathogen for tuberculosis. The minimum inhibitory concentration (MIC) values were determined according to [26], with slight modifications.

A stock solution of 20\% DMSO (Sigma-Aldrich, Saint Louis, MO, USA) was used to dissolve all tuber ethanolic extracts in Sterile Middlebrook 7H9 media. Furthermore, using this sterile media, two-fold dilutions were made of each sample into a final assay yield volume of $200 \mu \mathrm{L}$. Ciprofloxacin (Sigma-Aldrich, Saint Louis, MO, USA) served as a positive drug control at a concentration range of $0.156-10 \mu \mathrm{g} / \mathrm{mL}$. The solvent control (DMSO 2\%) as well as the untreated bacterial control were carried out in triplicates. The plates were sealed using parafilm before incubation at $37^{\circ} \mathrm{C}$ for $24 \mathrm{~h}$. After incubation of $24 \mathrm{~h}$, PrestoBlue (Thermofischer, South Africa) as a viability indicator was added to each well $(20 \mu \mathrm{L})$. The minimum inhibitory concentration (MIC) values were defined as the concentration at which no color change was visible from blue to pink.

\subsection{Antiproliferative Activity}

The antiproliferative activity assay was carried out according to the method of [27]. In all, $100 \mu \mathrm{L}$ of HepG2 cells with a cell density of 10,000 cells per well was seeded in 96 well plates after careful counting and left at $5 \% \mathrm{CO}_{2}$ and $37^{\circ} \mathrm{C}$ overnight to incubate in order to allow for attachment. To prepare each sample, a stock solution of $2000 \mu \mathrm{g} / \mathrm{mL}$ was used. A final test concentration of 12.5 to $400 \mu \mathrm{g} / \mathrm{mL}$ in serial dilutions of the sample extracts in the cell-containing plates was made. The plates were then incubated for $72 \mathrm{~h}$ at $37^{\circ} \mathrm{C}$ and $5 \% \mathrm{CO}_{2}$. Actinomycin D was used as the positive control (0.02 to $\left.0.5 \mu \mathrm{g} / \mathrm{mL}\right)$ and DMSO at $2 \%$ as the solvent control. After incubation, PrestoBlue was added $(20 \mu \mathrm{L})$ to each well, and the plates were left to incubate for a further 2-4 h. After incubation, the absorbance values were read (490 nm wavelength, including a reference wavelength of $690 \mathrm{~nm}$ ) using a BIO-TEK Power Wave XS multi-well reader. The mean $50 \%$ inhibitory values $\left(\mathrm{IC}_{50}\right)$ were calculated, and statistical analysis was performed.

\subsection{Statistical Analysis}

Data were collected on 52 samples (13 plants per cultivar) per treatment. Statistically significant differences among treatment means were determined by two-way analysis of variance (ANOVA) at $p<0.05$. Fisher's least significant difference (LSD) test was used to segregate means that were significantly different using a computer software program called STATISTICA (Palo Alto, California, USA). The mean $\mathrm{IC}_{50}$ values (three replicates) were used to perform statistical analysis using GraphPad Prism (Version 7, San Diego, CA, USA) and two-way ANOVA. To identify significance in comparison to the control value, the Dunnett's MCT was performed. All experiments were conducted in triplicates.

\section{Results}

3.1. Caffeic, Chlorogenic, and Ferulic acid Content in Solanum tuberosum L. Exposed to Higher Root Zone Temperature

The results of the present study revealed the presence of chlorogenic, caffeic, and ferulic acids in the ethanolic extracts of the potato tuber cultivars, as shown in Table 1. The chromatographic peaks in the result profiles showed some variations in the mean concentrations among the two root zone temperatures and the cultivars. Chlorogenic acid was the most prominent phenolic acid in both treatments and cultivars. Cultivar BP1 flesh and skins increased chlorogenic acid by $13 \%$ and $26 \%$, respectively, on exposure to an RZT of $24^{\circ} \mathrm{C}$. Similarly, cv. SB flesh and skins increased by $28 \%$ and $46 \%$, respectively, on 
exposure to an RZT of $24^{\circ} \mathrm{C}$. Although the set RZT of $24{ }^{\circ} \mathrm{C}$ significantly lowered caffeic acid in cv. BP1 skins and flesh $(0.29-0.03 \mu \mathrm{g} / \mathrm{g})$, the same RZT significantly increased this specific phenolic acid in the cv. SB skins $(0.39 \mu \mathrm{g} / \mathrm{g})$ and the flesh $(0.05 \mu \mathrm{g} / \mathrm{g})$. Interestingly, the control temperature (no heat applied) significantly increased the concentration of caffeic acid in BP1 skins $(0.367 \mu \mathrm{g} / \mathrm{g})$ and decreased the concentration in the flesh $(0.051 \mu \mathrm{g} / \mathrm{g})$. In addition, as shown in Table 1 , at $24^{\circ} \mathrm{C}$ the concentration of chlorogenic acid in cv. BP1 skins was lowered to $0.530 \mu \mathrm{g} / \mathrm{g}$ and in the BP1 flesh to $0.531 \mu \mathrm{g} / \mathrm{g}$; however, a set temperature of $24{ }^{\circ} \mathrm{C}$ had the ability to increase the concentration of chlorogenic acid in cv. SB skins $(0.779 \mu \mathrm{g} / \mathrm{g})$ and the flesh $(0.707 \mu \mathrm{g} / \mathrm{g})$. The control temperature significantly lowered the concentration of the chlorogenic acid in both cultivars. Ferulic acid was present, but in very low concentrations only in cv. SB. Using a two-way analysis of variance, a strong interaction was established between the specific cultivar and RZT on chlorogenic and caffeic acid contents in the present trial.

Table 1. The effect of root zone temperature on the phenolic acid content in S. tuberosum cv. BP1 and Salad blue.

\begin{tabular}{|c|c|c|c|c|c|c|}
\hline \multicolumn{3}{|c|}{ Caffeic Acid $(\mu g / g)$} & \multicolumn{2}{|c|}{ Chlorogenic Acid ( $\mu \mathrm{g} / \mathrm{g})$} & \multicolumn{2}{|c|}{ Ferulic Acid $(\mu \mathrm{g} / \mathrm{g})$} \\
\hline & Control & $24^{\circ} \mathrm{C}$ & Control & $24^{\circ} \mathrm{C}$ & Control & $24^{\circ} \mathrm{C}$ \\
\hline BP1 Skins & $0.37 \pm 0.004^{\mathrm{aA}}$ & $0.29 \pm 0.003^{\mathrm{bB}}$ & $0.39 \pm 0.006^{\mathrm{bC}}$ & $0.53 \pm 0.002^{\mathrm{aC}}$ & $0.00 \pm 0.001$ & $0.00 \pm 0.001$ \\
\hline $\begin{array}{c}\text { BP1 } \\
\text { Flesh }\end{array}$ & $0.05 \pm 0.001^{C}$ & $0.03 \pm 0.000^{\mathrm{C}}$ & $0.46 \pm 0.050^{\mathrm{bB}}$ & $0.53 \pm 0.003^{\mathrm{aC}}$ & $0.00 \pm 0.001$ & $0.00 \pm 0.001$ \\
\hline $\begin{array}{l}\text { SB } \\
\text { Skins }\end{array}$ & $0.25 \pm 0.003^{\mathrm{bB}}$ & $0.39 \pm 0.005^{\mathrm{aA}}$ & $0.42 \pm 0.005^{\mathrm{bBC}}$ & $0.78 \pm 0.014^{\mathrm{aA}}$ & $0.01 \pm 0.001$ & $0.01 \pm 0.001$ \\
\hline $\begin{array}{l}\text { SB } \\
\text { Flesh }\end{array}$ & $0.05 \pm 0.002^{C}$ & $0.05 \pm 0.001^{C}$ & $0.51 \pm 0.007^{\mathrm{bA}}$ & $0.71 \pm 0.007^{\mathrm{aB}}$ & $0.01 \pm 0.001$ & $0.01 \pm 0.001$ \\
\hline
\end{tabular}

Values represent mean \pm SD. Different small letters along the row per block represent significant differences at $p<0.05$ and different capital letters down the column represent significant differences at $p<0.05$. No heat was applied to the control. BP1 $=$ Non-pigmented control; $\mathrm{SB}=$ Salad Blue.

\subsection{Antimycobacterial Activity}

The antimycobacterial activity of Solanum tuberosum (ethanol extracts) of both cultivars and treatments of BP1 and SB was investigated. The ethanolic extracts of all the tested samples did not show activity at the highest test concentration of $1000 \mu \mathrm{g} / \mathrm{mL}$, as shown in Table 2. The positive drug control ciprofloxacin showed an MIC value of $0.325 \mu \mathrm{g} / \mathrm{mL}$.

Table 2. Antimycobacterial activity against M. smegmatis (MIC $\mu \mathrm{g} / \mathrm{mL}$ ).

\begin{tabular}{cc}
\hline & Antimycobacterial Activity against M. smegmatis $(\mathrm{MIC} \mu \mathrm{g} / \mathrm{mL})$ \\
\hline Control SB & NA \\
$24{ }^{\circ} \mathrm{C} \mathrm{SB}$ & NA \\
Control BP1 & NA \\
$24^{\circ} \mathrm{C} \mathrm{BP} 1$ & NA \\
\hline & Controls \\
Ciprofloxacin & 0.325 \\
\hline
\end{tabular}

NA-Not Active at the highest test concentration of $1000 \mu \mathrm{g} / \mathrm{mL}$.

\subsection{Antiproliferative Assay}

The antiproliferative ethanolic extract activity of S. tuberosum L. cultivars SB and BP1 subjected to two RZTs was tested against HepG2 liver cells. The $\mathrm{IC}_{50}$ values of the samples ranged between $267.7 \pm 36.17 \mu \mathrm{g} / \mathrm{mL}$ and $>400 \mu \mathrm{g} / \mathrm{mL}$, following $72 \mathrm{~h}$ of incubation as shown in Table 3. According to [28], after $72 \mathrm{~h}$ of incubation, plant extracts with $\mathrm{IC}_{50}$ values greater than $100 \mu \mathrm{g} / \mathrm{mL}$ are non-cytotoxic to the particular cell line. However, there is an increase in activity when SB and BP1 varieties are compared. 
Table 3. Antiproliferative activity against Hepatocellular carcinoma cells (HepG2) (IC50 $\mu \mathrm{g} / \mathrm{mL}$ ).

\begin{tabular}{cc}
\hline & $\begin{array}{c}\text { Antiproliferative Activity against Hepatocellular Carcinoma Cells } \\
\text { (HepG) }\left(\mathbf{I C}_{\mathbf{5 0}} \boldsymbol{\mu} \mathbf{g} / \mathbf{m L}\right)\end{array}$ \\
\hline Control SB & $267.7 \pm 36.17$ \\
$24{ }^{\circ} \mathrm{C} \mathrm{SB}$ & $290.8 \pm 39.35$ \\
Control BP1 & $393.0 \pm 34.17$ \\
$24{ }^{\circ} \mathrm{C} \mathrm{BP1}$ & $\mathrm{NA}$ \\
\hline & Controls \\
Actinomycin & $0.49 \pm 15.91$ \\
\hline NA-Not Active at the highest test concentration of $1000 \mu \mathrm{g} / \mathrm{mL}$.
\end{tabular}

\section{Discussion}

\subsection{Caffeic, Chlorogenic, and Ferulic acid Content in Solanum tuberosum L. Exposed to Higher Root Zone Temperature}

The results of the current study confirmed what was seen in the study conducted previously by [29], which showed that chlorogenic acid concentration was significantly lower in yellow-fleshed potatoes in comparison with the high values reported in colored potatoes. Furthermore, an elevated RZT showed minimal chlorogenic acid concentration increase. Interestingly, caffeic acid concentration increased when SB and BP1 were exposed to a higher RZT. The concentration of chlorogenic acid in red- or purple-fleshed cultivars has previously been reported to be 2.2 to 3.5 times higher than in yellow- and white-fleshed cultivars [30]. Similar results have been reported by other authors, including [31-35]. Phenolic compounds have a direct function in the type of response given by the plant when exposed to stress, such as from sun exposure or pathogen infection [36]. This is, therefore, a direct indication as to why the increase in RZT has a direct effect on the concentration of the phenolic, as seen in the current study.

\subsection{Antimycobacterial Activity}

Many literature studies have shown that the potato contains a variety of phenolic acids as a means of protection against microbes, viruses, and insects [37]. The mechanism of action of the antimicrobial potential of phenolic compounds has been proposed to be through the destabilization and permeation of the membrane of the microbe, which results in changes to the efflux activity and polarization; in addition, virulence factors, such as hydrophobicity, are directly affected [29]. A study conducted by [38] showed that the phenolic compound myricetin showed low antimycobacterial inhibition against M. smegmatis with an MIC value of $32 \mathrm{mg} / \mathrm{L}$. Another study conducted by [39] showed that chlorogenic acid showed no inhibition against $M$. smegmatis with an MIC value of $>2500 \mu \mathrm{g} / \mathrm{mL}$. Moreover, during this study, a direct correlation of phenolic content to antimycobacterial activity could not be shown [39]. Due to the high levels of chlorogenic acid found in both cultivars, it could be concluded that this might be why no inhibitory activity was found against $M$. smegmatis. Further studies based on previous literature could focus on the activity of chlorogenic acid against other Gram-negative and Gram-positive bacteria and microbes.

\subsection{Antiproliferative Activity}

Several studies have concluded that phenolics are important sources of antioxidants and that a diet rich in antioxidants can have remarkable effects on the risk of developing cardiovascular and neurogenerative diseases including cancer and diabetes [40-43]. The anticancer activity of chlorogenic acid was investigated both in vitro and in vivo against the HepG2 cell line and HepG2 xenografts in nude mice. The study concluded that chlorogenic acid in greater concentrations had increased inhibition of HepG2 cells. The xenograft studies on nude mice achieved the same results and showed the suppression of the progression of the HepG2 xenograft [44]. Although there was no effective antiproliferative activity, as seen in the results against the HepG2 cell line by both the cultivars tested, it 
should be noted that the increase in chlorogenic acid content in the SB cultivar showed increased antiproliferative activity when compared with BP1. It should also be emphasized that although chlorogenic acid is present in high amounts in both cultivars, it is not the only phenolic compound, or compound in general, that is present, and the synergistic effects of all compounds in Solanum tuberosum L. should be noted when looking at antiproliferative activity.

\section{Conclusions}

The pigmented potato tubers' antioxidant capacity (through the presence of ferulic, chlorogenic, and caffeic acids), antiproliferative activity, and antimycobacterial activity are cultivar specific. In our study, increasing the RZT had a significant effect on caffeic and chlorogenic acid in the pigmented cultivar SB. The same effect was reported in the antiproliferative study. Our results may offer the opportunity to test the same and other cultivars of Solanum tuberosum against other cancer cell lines. These findings are of interest because they increase the availability of information on the experimental investigations of different cultivars found within Southern Africa.

Author Contributions: Conceptualization, L.K., N.L., O.O.O. and H.W.; methodology, L.K., O.O.O. and N.L.; software, validation, and formal analysis, A.-M.R.; investigation, H.W. and A.-M.R.; resources, L.K., O.O.O. and N.L.; data curation, A.-M.R. and H.W.; writing-original draft preparation, H.W.; writing-review and editing, C.B.; supervision, L.K., O.O.O., N.L. and C.B.; project administration, L.K.; funding acquisition, L.K., O.O.O. and N.L. All authors have read and agreed to the published version of the manuscript.

Funding: This research received no external funding.

Institutional Review Board Statement: Not applicable.

Informed Consent Statement: Not applicable.

Data Availability Statement: Not applicable.

Conflicts of Interest: The authors declare no conflict of interest.

\section{References}

1. Birch, P.R.J.; Bryan, G.; Fenton, B.; Gilroy, E.M.; Hein, I.; Jones, J.T.; Prashar, A.; Taylor, M.A.; Torrance, L.; Troth, I.K. Crops that feed the world 8: Potato: Are the trends of increased global production sustainable? Food Secur. 2012, 4, 477-508. [CrossRef]

2. FAO. 2021a. Potato Production Worldwide from 2002 to 2019 (in Million Metric Tons). Statista Inc. Available online: https: //www-statista-com.libproxy.cput.ac.za/statistics/382174/global-potato-production/ (accessed on 9 June 2021).

3. FAO. 2021b. Potato Production Worldwide in 2019, by Leading Country (in Million Metric Tons). Statista Inc. Available online: https: / / www-statista-com.libproxy.cput.ac.za/statistics/382192/global-potato-production-by-country/ (accessed on 9 June 2021).

4. POTATOPRO. 2021. South Africa Potato Statistics. Available online: https://www.potatopro.com/south-africa/potato-statistics (accessed on 9 June 2021).

5. Sonia, N.S.; Mini, C.; Geethalekshmi, P.R. Vegetable peels as natural antioxidants for processed foods-A review. Agric. Rev. 2016, 37, 35-41. [CrossRef]

6. Tiwari, B.K.; Valdramidis, V.; Donnell, C.P.O.; Muthukumarappan, K.; Bourke, P.; Cullen, P.J. Application of Natural Antimicrobials for Food Preservation. J. Agric. Food Chem. 2009, 57, 5987-6000. [CrossRef]

7. Pezeshk, S.; Ojagh, S.; Alishahi, A. Effect of plant antioxidant and antimicrobial compounds on the shelf-life of seafood-A review. Czech J. Food Sci. 2016, 33, 195-203. [CrossRef]

8. Orsted, H.; Keast, D.; Forest-Lalande, L.; Mégie, M.F. Basic principles of wound healing an understanding of the basic physiology of wound healing provides. Wound Care Can. 2004, 9, 1-5.

9. Dudek, N.; Maria, M.D.; Horta, P.; Hermes, D.; Sanches, C.C.; Modolo, L.V.; Lima, E.N. In vivo wound healing and antiulcer properties of white sweet potato (Ipomoea batatas). J. Adv. Res. 2013, 4, 411-415.

10. Ginzberg, I.; Tokuhisa, J.G.; Veilleux, R.E. Potato steroidal Glycoalkaloids: Biosynthesis and genetic manipulation. LifeEarth Health Sci. 2009, 52, 1-15. [CrossRef]

11. McCue, K.F. Potato glycoalkaloids, Past Present and Future E-lycotetraose; Harvard University: Chicago, IL, USA, 2009.

12. Witbooi, H.; Kambizi, L.; Oguntibeju, O. An alternative health crop for South Africa: Purple potato mini tuber production as affected by water and nutrient stress. Afr. J. Food Agric. Nutr. Dev. 2020, 20, 16818-16831. [CrossRef] 
13. Friedman, M. Chemistry, Biochemistry, and Dietary Role of Potato Polyphenols. A Review. J. Agric. Food Chem. 1997, 45, 1523-1540. [CrossRef]

14. Riciputi, Y.; Diaz-de-Derio, E.; Akyol, H.; Capanoglu, E.; Cerretani, L.; Caboni, M.F.; Verardo, V. Establishment of ultrasound assisted extraction of phenolic compounds from industrial potato by-products using response surface methodology. Food Chem. 2018, 269, 258-263. [CrossRef]

15. Boker, L.K.; Van der Schouw, Y.T.; De Kleijn, M.J.; Jacques, P.F.; Grobbee, D.E.; Peters, P.H. Intake of dietary phytoestrogens by Dutch women. J. Nutr. 2002, 132, 1319-1328. [CrossRef] [PubMed]

16. Dragsted, L.O.; Strube, M.; Leth, T. Dietary levels of plant phenols and other non-nutritive components: Could they prevent cancer? Eur. J. Cancer Prev. 1997, 6, 522-528. [CrossRef]

17. Hertog, M.G.; Bueno-De-Mesquita, H.B.; Fehily, A.M.; Sweetnam, P.M.; Elwood, P.C.; Kromhout, D. Fruit and vegetable consumption and cancer mortality in the Caerphilly Study. Cancer Epidemiol. Biomark. Prev. 1996, 5, 673-677.

18. Knekt, P.; Kumpulainen, J.; Jarvinen, R.; Rissanen, H.; Heliovaara, M.; Reunanen, A.; Hakulinen, T.; Aromaa, A. Flavanoid intake and risk of chronic diseases. Am. J. Clin. Nutr. 2002, 76, 560-568. [CrossRef]

19. Hayashi, K.; Hibasami, H.; Murakami, T.; Terahara, N.; Mori, M.; Tsukui, A. Induction of Apoptosis in Cultured Human Stomach Cancer Cells by Potato Anthocyanins and Its Inhibitory Effects on Growth of Stomach Cancer in Mice. Food Sci. Technol. Res. 2006, 12, 22-26. [CrossRef]

20. Reddivari, L.; Hale, A.L.; Miller, J.C., Jr. Determination of phenolic content, composition and their contribution to antioxidant activity in specialty potato selections. Am. J. Potato Res. 2007, 84, 275-282. [CrossRef]

21. Madiwale, G.P.; Reddivari, L.; Holm, D.G.; Vanamala, J. Storage elevates phenolic content and antioxidant activity but suppresses antiproliferative and pro-apoptotic properties of colored-flesh potatoes against human colon cancer cell lines. J. Agric. Food Chem. 2011, 59, 8155-8166. [CrossRef]

22. Wang, Q.; Chen, Q.; He, M.; Mir, P.; Su, J.; Yang, Q. Inhibitory effect of antioxidant extracts from various potatoes on the proliferation of human colon and liver cancer cells. Nutr. Cancer 2011, 63, 1044-1052. [CrossRef]

23. Friedman, M.; Lee, K.-R.; Kim, H.-J.; Lee, I.-S.; Kozukue, N. Anticarcinogenic Effects of Glycoalkaloids from Potatoes against Human Cervical, Liver, Lymphoma, and Stomach Cancer Cells. J. Agric. Food Chem. 2005, 53, 6162-6169. [CrossRef]

24. Lee, K.-R.; Kozukue, N.; Han, J.-S.; Park, J.-H.; Chang, E.-Y.; Baek, E.-J.; Chang, J.-S.; Friedman, M. Glycoalkaloids and Metabolites Inhibit the Growth of Human Colon (HT29) and Liver (HepG2) Cancer Cells. J. Agric. Food Chem. 2004, 52, 2832-2839. [CrossRef]

25. Witbooi, H.; Bvenura, C.; Oguntibeju, O.O.; Kambizi, L. The role of root zone temperature on physiological and phytochemical compositions of some pigmented potato (Solanum tuberosum L.) cultivars. Cogent Food Agric. 2021, 7, 1905300. [CrossRef]

26. Lall, N.; Henley-Smith, C.J.; De Canha, M.N.; Oosthuizen, C.B.; Berrington, D. Viability Reagent, PrestoBlue, in Comparison with Other Available Reagents, Utilized in Cytotoxicity and Antimicrobial Assays. Int. J. Microbiol. 2013, 2013, 420601. [CrossRef]

27. Berrington, D.; Lall, N. Anticancer Activity of Certain Herbs and Spices on the Cervical Epithelial Carcinoma (HeLa) Cell Line. Evid.-Based Complement. Altern. Med. 2012, 2012, 564927. [CrossRef] [PubMed]

28. Lewis, C.E.; Walker, J.R.L.; Lancaster, J.E.; Sutton, K.H. Determination of anthocyanins, flavonoids and phenolic acids in potatoes. I: Coloured cultivars of Solanum tuberosum L. J. Sci. Food Agric. 1998, 77, 45-57. [CrossRef]

29. Akyol, H.; Riciputi, Y.; Capanoglu, E.; Caboni, M.F.; Verardo, V. Phenolic compounds in the potato and its by-products: An overview. Int. J. Mol. Sci. 2016, 27, 835. [CrossRef] [PubMed]

30. Ezekiel, R.; Singh, N.; Sharma, S.; Kaur, A. Beneficial phytochemicals in potato-A review. Food Res. Int. 2013, 50, 487-496. [CrossRef]

31. Furrer, A.; Cladis, D.; Kurilich, A.; Manoharan, R.; Ferruzzi, M.G. Changes in phenolic content of commercial potato varieties through industrial processing and fresh preparation. Food Chem. 2017, 218, 47-55. [CrossRef]

32. Külen, O.; Stushnoff, C.; Holm, D.G. Effect of cold storage on total phenolics content, antioxidant activity and vitamin C level of selected potato clones. J. Sci. Food Agric. 2013, 93, 2437-2444. [CrossRef]

33. Lachman, J.; Hamouz, K.; Musilová, J.; Hejtmánková, K.; Kotiková, Z.; Pazderū, K.; Domkárová, J.; Pivec, J.; Cimr, J. Effect of peeling and three cooking methods on the content of selected phytochemicals in potato tubers with various colour flesh. Food Chem. 2013, 138, 1189-1197. [CrossRef]

34. Stushnoff, C.; Holm, D.; Thompson, M.D.; Jiang, W.; Thompson, H.J.; Joyce, N.; Wilson, P. Antioxidant Properties of Cultivars and Selections from the Colorado Potato Breeding Program. Am. J. Potato Res. 2008, 85, 267-276. [CrossRef]

35. Gibbons, S. Anti-staphylococcal plant natural products. Nat. Prod. Rep. 2004, 21, 263-277. [CrossRef]

36. Geran, R.I.; Greenberg, N.H.; McDonald, M.M.; Schumacher, A.M.; Abbott, B.J. Protocols for screening chemical agents and natural products against animal tumour and other biological systems. Cancer Chemother. Rep. 1972, 3, 17-19.

37. Ngadze, E.; Coutinho, T.; Icishahayo, D.; van der Waals, J. Effect of calcium soil amendments on phenolic compounds and soft rot resistance in potato tubers. Crop. Prot. 2014, 62, 40-45. [CrossRef]

38. Lima, M.; de Sousa, C.P.; Fernandez-Prada, C.; Harel, J.; Dubreuil, J.; de Souza, E. A review of the current evidence of fruit phenolic compounds as potential antimicrobials against pathogenic bacteria. Microb. Pathog. 2019, 130, 259-270. [CrossRef] [PubMed]

39. Lechner, D.; Gibbons, S.; Bucar, F. Plant phenolic compounds as ethidium bromide efflux inhibitors in Myco-bacterium smegmatis. J. Antimicrob. Chemother. 2008, 62, 345-348. [CrossRef] [PubMed] 
40. Da Cruz, R.C.; Agertt, V.; Boligon, A.A.; Janovik, V.; de Campos, M.M.A.; Guillaume, D.; Athayde, M.L. In vitro antimycobacterial activity and HPLC-DAD screening of phenolics from Ficus benjamina L. and Ficus luschnathiana (Miq.) Miq. Leaves. Nat. Prod. Res. 2012, 26, 2251-2254. [CrossRef] [PubMed]

41. Fernandez-Panchon, M.S.; Villano, D.; Troncoso, A.M.; Garcia-Parrilla, M.C. Antioxidant activity of phenolic compounds: From in vitro results to in vivo evidence. Crit. Rev. Food Sci. Nutr. 2008, 48, 649-671. [CrossRef]

42. Hollman, P.; Katan, M. Dietary Flavonoids: Intake, Health Effects and Bioavailability. Food Chem. Toxicol. 1999, 37, 937-942. [CrossRef]

43. Sato, M.; Ramarathnam, N.; Suzuki, Y.; Ohkubo, T.; Takeuchi, M.; Ochi, H. Varietal differences in the phenolic content and superoxide radical scavenging potential of red wines from different sources. J. Agric. Food Chem. 1996, 44, 37-41. [CrossRef]

44. Scalbert, A.; Manach, C.; Morand, C.; Rémésy, C.; Jiménez, L. Dietary Polyphenols and the Prevention of Diseases. Crit. Rev. Food Sci. Nutr. 2005, 45, 287-306. [CrossRef] 